\title{
Effect of zeolites on soil modification and productivity
}

\author{
Liliya M.-H. Bikkinina ${ }^{1, *}$, Vladimir O. Ezhkov ${ }^{1}$, Ramil N. Faizrakhmanov ${ }^{2}$, Rasim R. Gazizov ${ }^{1}$, and Asiya M. Ezhkova ${ }^{1}$ \\ ${ }^{1}$ Tatar Scientific Research Institute of Agrochemistry and Soil Science, FRC Kazan Scientific Center, Russian Academy of Sciences, \\ 420059 Kazan, Russia \\ ${ }^{2}$ Kazan State Academy of Veterinary Medicine named after N.E. Bauman, 420029 Kazan, Russia
}

\begin{abstract}
Local natural zeolite-containing rocks use efficiency in agriculture of the Republic of Tatarstan was studied in the research. The research was conducted in the field on leached black soil applying mechanoactivated zeolites and in greenhouses on grey forest soil using nanostructured zeolite. Field experiments identified the soil deacidification of $0.4 \mathrm{pH}_{\text {sol }}$, increase of assimilable phosphates of the $1^{\text {st }}$ and $2^{\text {nd }}$ groups (Ca-P1 и Сa-P2) - of 5.0 and $6.6 \mathrm{mg}$ per $100 \mathrm{~g}$ of soil. Moreover, the research considered the increasing the mobile phosphorus available to plants - of 8.0 and $10.0 \mathrm{mg} / \mathrm{kg}$ and exchange potassium of 5.0 and $6.6 \mathrm{mg} / \mathrm{kg}$ according to the doses of zeolite of 10 and $15 \mathrm{t} / \mathrm{ha}$. Improving the activity of microflora in rhizosphere and growth acceleration of microbial biomass to $15.5 \mathrm{mg}$ per $100 \mathrm{~g} * \mathrm{~h}$ were observed. The average annual grain yield gain was 0.3 and $0.5 \mathrm{t} / \mathrm{ha}$, and the payback of 1 ton of zeolite by additional harvest 0.11 and $0.09 \mathrm{t} / \mathrm{ha}$ in grain units respectively. Improvement in the reaction of the soil environment was stated in the vegetative conditions on gray forest soil using nanostructured zeolite in doses of 0.1 and $1.0 \mathrm{t} / \mathrm{ha}$, a positive shift in $\mathrm{pH}_{\mathrm{sol}}$, was 0.97 and 0.9 units respectively. Under the influence of mechanically activated celite at a dose of $15 \mathrm{t} / \mathrm{ha}$, soil acidity decreased by $0.99 \mathrm{pH}_{\mathrm{sol}}$ units. The use of nanostructured zeolite contributed to an increase of the reserves of ammonia nitrogen in the soil - by 0.8 and $2.4 \mathrm{mg} / \mathrm{kg}$, mobile phosphorus - by 6.0 and $33.0 \mathrm{mg} / \mathrm{kg}$, and exchangeable potassium - by 3.0 and $5.5 \mathrm{mg} / \mathrm{kg}$ respectively at doses of 0.1 and 1.0 t/ha respectively. The growth of microbial biomass was up to $24.0 \mathrm{mg} / 100 \mathrm{~g} * \mathrm{~h}$. Additional grain gains were obtained: under the influence of mechanically activated zeolite at a dose of $15 \mathrm{t} / \mathrm{ha}-8.6 \mathrm{~g} / \mathrm{vessel}$ and nanostructured analog at a dose of $0.1 \mathrm{t} / \mathrm{ha}-7.3 \mathrm{~g} / \mathrm{vessel}$, which were comparable at the consumption of the latter 150 times less.
\end{abstract}

\section{Introduction}

The territory of Republic of Tatarstan possesses rich deposits of phosphorites, glauconites, bentonites and other types of mineral raw materials of natural origin. In recent years particular attention is being paid to searching for new, non-traditional sources of raw materials aiming to restore soil fertility. This issue is particularly connected with the high cost of industrial mineral fertilizers and the need to involve minerals in production activities minimally impacting the biosphere [1-3].

Among the local energy-intensive mineral raw materials the zeolite-containing rocks were of special interest. Natural zeolites are characterized by a significant absorption capacity $(100-300 \mathrm{cmol}(\mathrm{eq}) / \mathrm{kg})$, active sorption and ion-exchange properties, and the ability to reverse degradation. Zeolites can significantly regulate the mineral nutrition of plants in soil, as they contain calcium, magnesium, potassium, phosphorus and a number of trace elements. They can be one of the components of complex fertilizer $[4,5]$.

The action of zeolites in the soil increases the content of mineral nitrogen, especially ammonium as a result of the sorption capacity for the cation ammonium.
Herewith, ammonium absorbed by the zeolite in the cavity of the crystal lattice is not lost from the soil during nitrification, but is given to plants during the vegetation development. The high sorption capacity of zeolites in regards to the ammonium cation is indicated by field experiments with concentrated zeolite and urea, where the decrease in ammonia volatilization losses was $8.0 \%$ [6]. The use of Tatarstan zeolites in greenhouse vegetable farming, where the soil problem is acute, contributes to an increase in the density of the soil (peat) - by $11.0-12.0 \%$ with a $25 \%$ dose of zeolitecontaining rocks [7].

Zeolites take an active part not only in plant nutrition, but also in improving the agrochemical and agrophysical properties of the soil, which was experimentally confirmed by the experiments of B.A. Sushenitsa (2007). The author reported that on a gray forest soil in the year of direct action of zeolitecontaining rocks, the shift of $\mathrm{pH}_{\mathrm{sol}}$ with moderate doses of mineral fertilizers amounted to $0.34-0.68$ units, and at higher doses NPK - to 0.18-0.52 units [8].

Of special interest were studies of complex organomineral fertilizers, created on the basis of natural zeolites and cattle farm runoff, which allow concluding about the effectiveness of products obtained from recycled organic

* Corresponding author: liliyaagro@mail.ru 
clusters. The use of such fertilizer contributed not only to improvement of the agrochemical properties of the soil, but also increased the activity of biological processes in the soil. At the same time, the yield gain in grain of spring rapeseed was $-32.0-6.0 \%$ [9].

There are studies showing the prospects for the use of natural minerals in nanostructured form, which can make a significant contribution to improving the efficiency of agricultural production [4]. Its use as a fertilizer can potentially contribute to an increase in food production, as high availability of mineral nanoparticles will allow controlling the concentration of fertilizers in a perfect range [10-12].

The purpose of the research is to study the effect of various doses and forms of zeolites of the TatarShatrashanskoye deposit of the Republic of Tatarstan in combination with mineral fertilizers on the increase in the fertility of the studied soils.

\section{Materials and methods}

Studies using natural zeolite were carried out in 20152017 in stationary single-factor field experiment in the Buinsky district of the Republic of Tatarstan and in green house on the basis of the Tatar Research Institute of Agrochemistry and Soil Science, FRC Kazan Scientific Center, Russian Academy of Sciences. In field experiments, the studied soil was a leached black soil (medium thick heavy loamy). The agrochemical characteristics of the tilth top soil $(0-25 \mathrm{~cm})$ before laying the experience is as follows: humus $-6.7 \%, \mathrm{pH}_{\text {sol }}$ -5.1 , hydrolytic acidity $(\mathrm{Hr})$ and the amount of absorbed bases (S) - 4.9 and $49.2 \mathrm{cmol}(\mathrm{eq}) / \mathrm{kg}$, degree of base saturation $(\mathrm{V})-91.0 \%$, mobile phosphorus $\left(\mathrm{P}_{2} \mathrm{O}_{5}\right)$ and exchangeable potassium $\left(\mathrm{K}_{2} \mathrm{O}\right)-161.0$ and $148.0 \mathrm{mg} / \mathrm{kg}$, respectively.

Field studies were carried out according to the scheme of the experiment: 1) control - without fertilizers; 2) mineral fertilizers $\left(\mathrm{N}_{60} \mathrm{P}_{60} \mathrm{~K}_{60}\right) \quad-$ background; 3 ) background + mechanically activated zeolite at a dose of $10 \mathrm{t} / \mathrm{ha} ; 4)$ background + mechanically activated zeolite at a dose of $15 \mathrm{t} / \mathrm{ha}$.

The mechanically activated zeolite was embedded in the soil since autumn after harvesting spring wheat, and mineral fertilizers were applied annually before sowing crops.

Mechanically activated zeolite was obtained by grinding the zeolite-containing rock in the crushing and screening plants. The fraction of particles was: under $0.25 \mathrm{~mm}-25 \%, 0.25-0.50 \mathrm{~mm}-14.25 \%, 1.0 \mathrm{~mm}-$ $59.5 \%$, to $2.00 \mathrm{~mm}-1.25 \%$.

The chemical composition of natural zeolite was determined by quantitative spectral analysis on an ES-1 spectrometer based on a DFS-458S diffraction spectrograph and a photoelectronic recording device of the FP-4 type: $\mathrm{SiO}_{2}-57.0 \%, \mathrm{SiO}_{2}$ amorphous $-27.0 \%$, $\mathrm{CaO}-14.43 \%, \mathrm{MgO}-1.86 \%, \mathrm{P}_{2} \mathrm{O}_{5}-0.08 \%, \mathrm{~K}_{2} \mathrm{O}-$ $1.10 \%, \mathrm{Na}_{2} \mathrm{O}-0.20 \%, \mathrm{Fe}_{2} \mathrm{O}_{3}-1.90 \%, \mathrm{Mn}-0.01 \%$, $\mathrm{Cu}-0.001 \%, \mathrm{Zn}-0.003 \%, \mathrm{Co}-0.011 \%, \mathrm{Ni}-0.04$, $\mathrm{Pb}-0.004 \%$.
The studied soil in the vegetation experiments is gray forest medium loamy soil. Initial agrochemical parameters: humus $-3.5 \%, \mathrm{pH}_{\mathrm{sol}}-5.5, \mathrm{Hr}-1.5 \mathrm{cmol}$ (eq) $/ \mathrm{kg}$ of soil, $\mathrm{S}-21.2 \mathrm{cmol}(\mathrm{eq}) / \mathrm{kg}, \mathrm{V}-93 \%, \mathrm{P}_{2} \mathrm{O}_{5}-$ $161.0 \mathrm{mg} / \mathrm{kg}, \mathrm{K}_{2} \mathrm{O}-108.0 \mathrm{mg} / \mathrm{kg}$.

The experiment scheme included 1) control - without fertilizers; 2) mineral fertilizers $\left(\mathrm{N}_{60} \mathrm{P}_{60} \mathrm{~K}_{60}\right)_{-}$ background; 3) background + mechanically activated zeolite at a dose of $15 \mathrm{t} / \mathrm{ha}$; 4) background + nanostructured zeolite at a dose of $0.1 \mathrm{t} / \mathrm{ha}$; background + nanostructured zeolite at a dose of $1.0 \mathrm{t} / \mathrm{ha}$.

Studies were conducted using Wagner vessels, in which soil weighing $5 \mathrm{~kg}$ was packed. Mineral fertilizers were added to the soil during the period of the vessel filling. The experiment analyzed the effectiveness of nanostructured zeolite in the cultivation of buckwheat (Fagopyrum esculentum), cultivar Cheremshanka. As a comparison, mechanically activated zeolite was used at a dose of $15 \mathrm{t} / \mathrm{ha}$.

A nanostructured zeolite was made at the Nanomaterials and Nanotechnologies Research and Development Center in Kazan using ultrasound on mechanically activated zeolite in a UZU-0.25 device (Russia). The frequency was $18.5 \mathrm{kHz}( \pm 10 \%)$ (power density - $80 \mathrm{~W} / 1$, the amplitude of the ultrasound waveguide $5 \mu \mathrm{m}$ ); duration of the treatment was 20 minutes.

The structure of zeolites and some physical properties (shape, particle size, size distribution) in the phase of macro and nanoscopic dispersions were studied in the Spectroscopy, Microscopy and Thermal Analysis laboratory of the Nanomaterials and Nanotechnology Research and Development Center in Kazan using methods of intermittent contact atomic-force microscopy on a MultiModeV scanning probe microscope by Veeco (USA). Survey procedure was the following: the specimen were prepared from an aqueous solution of the powder previously dispersed in an ultrasonic installation UZU-0.25 and in the form of an aqueous (deionized water) solution of the powder by applying a drop on a substrate of mica with subsequent deposition. The specialists used substrates with dimensions of $1 \mathrm{x} 1 \mu \mathrm{m}^{2}$, $5 \times 5 \mathrm{~m}^{2}, 10 \times 10 \mu \mathrm{m}^{2}, 20 \times 20 \mu \mathrm{m}^{2}, 50 \times 50 \mu \mathrm{m}^{2}$ for scanning.

When studying the AFM images of the surface topography of a nanostructured zeolite, a significant decrease in particle size and an increase in their number was observed, that is a consequence of the splitting of the zeolite conglomerates into constituent particles. There were more than a hundred particles on the area of 10x10 $\mu \mathrm{m} 2$ which were visualized as sputtering and showing an increase in the physical area of the substance. The particles had a volumetric irregular round-oval shape of three sizes: $5.0-20.0 \mathrm{~nm}$ representing a $55.0 \%, 25.0-30.0 \mathrm{~nm}-35.0 \%$, and $35.0-100.0 \mathrm{~nm}-10.0 \%$. In the field of vision of the substrate 3-5 single large formations with sizes greater than $100.0 \mathrm{~nm}$ were observed in the same sample. A detailed study found that they were a system consisting of the above-mentioned small particles. The histogram shows the distribution of particles ranging in size from 25.0 to $30.0 \mathrm{~nm}$. 
Thus, in the process of ultrasonic dispersion of zeolite from the macrodispersion phase to the nanostructured phase, a decrease in the particle size with a change in their shape and an increase in the amount were observed, which would undoubtedly cause a change in the known properties of the mineral. The dispersion of conglomerates causes an increase in the physical area and will contribute to an increase in the contact area, while scattered particles with open chemical bonds will increase the activity of the zeolite.

The respiratory activity of the soil microbial community was studied by the method of titrimetric determination of the amount of carbon dioxide $\left(\mathrm{CO}_{2}\right)$ released after alkali absorption [9].

\section{Results}

The acidity of leached black soil (chernozem) under the influence of background mineral fertilizers has noticeably increased, and compared with the control the $\mathrm{pH}$ shift in these variants was 0.1 units. A similar picture was observed with the hydrolytic acidity $(\mathrm{Hr})$ of the soil, where an increase in the $\mathrm{Hr}$ index relative to the control was $0.2 \mathrm{cmol}(\mathrm{eq}) / \mathrm{kg}$ of soil (Table 1).

Table 1. Effect of mechanically activated zeolite on agrochemical properties of leached chernozem

\begin{tabular}{|c|c|c|c|c|c|c|}
\hline Variant & 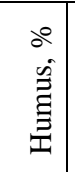 & 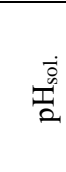 & 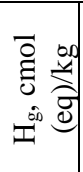 & $\begin{array}{l}\overrightarrow{0} \\
\text { : } \\
\text { is } \\
\dot{y}\end{array}$ & 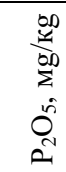 & 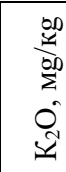 \\
\hline Control & 6.6 & 5.0 & 4.5 & 52.6 & 155 & 147 \\
\hline $\mathrm{N}_{60} \mathrm{P}_{60} \mathrm{~K}_{60}-$ background & 6.6 & 4.9 & 4.7 & 53.8 & 155 & 160 \\
\hline Background $+\mathrm{MZ}^{*} 10 \mathrm{t} / \mathrm{ha}$ & 6.7 & 5.3 & 3.7 & 54.2 & 163 & 164 \\
\hline Background + MZ 15 t/ha & 6.6 & 5.3 & 3.5 & 55.7 & 165 & 165 \\
\hline $\mathrm{DLS}_{05}$ & 0.14 & 0.15 & 0.12 & 2.13 & 5.25 & 3.84 \\
\hline
\end{tabular}

Note: MZ* - mechanically activated zeolite

The introduction of mechanically activated zeolite into the soil in doses of 10 and $15 \mathrm{t} / \mathrm{ha}$ contributed to the partial neutralization of the soil's exchangeable acidity. The shift in $\mathrm{pH}_{\text {sol }}$ relative to the initial acidity of the soil (5.1) was - by 0.2 units, background - by 0.4 units, respectively, to the doses.

A similar neutralizing effect of mechanically activated zeolite was also noted on the decrease in hydrolytic acidity of the soil. The Hr values were lower than the background values - by 1.0 and $1.2 \mathrm{cmol}$ (eq) $/ \mathrm{kg}$, respectively, to doses of the mineral 10 and 15 t/ha.The use of mechanically activated zeolite had a positive effect on the soil absorbing complex. The number of exchangeable cations in the soil, depending on the doses of mineral at 10 and $15 \mathrm{t} / \mathrm{ha}$, exceeded the initial indicator $(49.2 \mathrm{cmol}(\mathrm{eq}) / \mathrm{kg}$ ) by 5.0 and $6.5 \mathrm{cmol}$ (eq)/kg, the background indicator - by 0.4 and $1.9 \mathrm{cmol}$ ( eq) $/ \mathrm{kg}$ of soil, respectively.

An increase in the content of phosphorus available to plants was noted in the studied soil. According to Table 1 the amount of mobile phosphorus in the soil was high relative to the initial value $(161.0 \mathrm{mg} / \mathrm{kg})$ - by 2.0 and $4.0 \mathrm{mg} / \mathrm{kg}$, background - by 8.0 and $10.0 \mathrm{mg} / \mathrm{kg}$, respectively, increasing doses of the mineral.

Table 2 presents the results of studies of the group composition of phosphates. The addition of mechanically activated zeolite to the soil contributed to the increase in the sum of the first and second fractions of available phosphates $\left(\mathrm{Ca}-\mathrm{P}_{1}\right.$ and $\left.\mathrm{Ca}-\mathrm{P}_{2}\right)$, which amounted to 5.0 and $6.6 \mathrm{mg} / 100 \mathrm{~g}$ of soil, respectively, at doses of 10 and $15 \mathrm{t} / \mathrm{ha}$ compared to the background. Upward or downward changes were observed to a lesser extent in the precipitated tricalcium phosphate form $\left(\mathrm{Ca}-\mathrm{P}_{3}\right)$

Table 2. Effect of mechanically activated zeolite on the group composition of phosphate of leached chernozem, mg/100g

\begin{tabular}{|c|c|c|c|c|c|c|c|}
\hline Variant & $\mathrm{Ca}-\mathrm{P}_{1}$ & $\mathrm{Ca}-\mathrm{P}_{2}$ & Al-P & $\mathrm{Fe}-\mathrm{P}$ & $\mathrm{Ca}-\mathrm{P}_{3}$ & 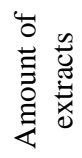 & 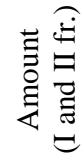 \\
\hline Control & 10.2 & 8.7 & 4.7 & 7.5 & 17.3 & 48.4 & 18.9 \\
\hline $\begin{array}{l}\mathrm{N}_{60} \mathrm{P}_{60} \mathrm{~K}_{60}- \\
\text { background }\end{array}$ & 10.0 & 8.8 & 4.8 & 7.5 & 17.3 & 48.4 & 18.8 \\
\hline $\begin{array}{c}\text { Background + } \\
\text { MZ } 10 \text { t/ha }\end{array}$ & 14.7 & 9.1 & 4.9 & 7.7 & 17.6 & 54.0 & 23.8 \\
\hline $\begin{array}{c}\text { Background + } \\
\text { MZ } 15 \mathrm{t} / \mathrm{ha}\end{array}$ & 16.2 & 9.2 & 4.8 & 7.6 & 17.4 & 55.2 & 25.4 \\
\hline
\end{tabular}

The use of mechanically activated zeolite contributed to an increase in the content of mobile potassium in the soil, compared with the baseline $(148.0 \mathrm{mg} / \mathrm{kg})$ by 16.0 and $17.0 \mathrm{mg} / \mathrm{kg}$, with a background by 4.0 and $5.0 \mathrm{mg} / \mathrm{kg}$ of soil, respectively, at doses of 10 and 15 t/ha.

It is known that there is a dynamic equilibrium between the forms of potassium in the soil. As the mobile potassium intake by plants is consumed, its reserves will be replenished due to non-exchange, including from the crystal lattice of agrominerals. The content of exchangeable potassium under the influence of mechanically activated zeolite in the soil increased by 24.0 and $33.0 \mathrm{mg} / \mathrm{kg}$ of soil, respectively, at doses of 10 and $15 \mathrm{t} /$ ha to the background (Table 3 ).

Table 3. Effect of mechanically activated zeolite on the dynamics of forms of potassium of leached chernozem, $\mathrm{mg} / \mathrm{kg}$

\begin{tabular}{|c|c|c|c|c|c|}
\hline Variant & 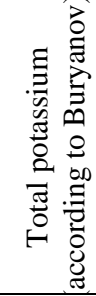 & 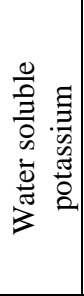 & 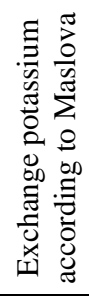 & 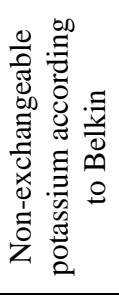 & 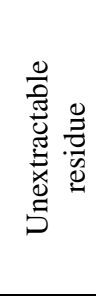 \\
\hline Control & 14300 & 10 & 294 & 1654 & 12341 \\
\hline $\begin{array}{l}\mathrm{N}_{60} \mathrm{P}_{60} \mathrm{~K}_{60}- \\
\text { background }\end{array}$ & 14600 & 15 & 320 & 1535 & 12730 \\
\hline $\begin{array}{c}\text { background + } \\
\text { MZ } 10 \mathrm{t} / \mathrm{ha}\end{array}$ & 14600 & 15 & 344 & 1481 & 12760 \\
\hline $\begin{array}{c}\text { background + } \\
\text { MZ } 15 \mathrm{t} / \mathrm{ha}\end{array}$ & 15300 & 16 & 353 & 1491 & 13440 \\
\hline
\end{tabular}


An important factor in soil fertility is an increase in the activity of microflora in the rhizosphere - the soil area of the active interaction of soil microorganisms and plants. Microbiological activity characterizes the parameters of soil respiration.

Table 4. Effect of mechanically activated zeolite on basal respiration and microbial soil biomass

\begin{tabular}{|c|c|c|}
\hline Variant & $\begin{array}{c}\text { Basal respiration, } \\
\mathrm{mg} / 100 \mathrm{~g} * 24 \\
\text { hours }\end{array}$ & $\begin{array}{c}\text { Microbial } \\
\text { biomass, } \\
\text { mg/100 g*h }\end{array}$ \\
\hline Control & 9.9 & 33.1 \\
\hline $\mathrm{N}_{60} \mathrm{P}_{60} \mathrm{~K}_{60}-$ background & 11.1 & 28.6 \\
\hline Background + MZ 10 т/га & 12.9 & 33.3 \\
\hline Background + MZ 15 т/га & 14.2 & 44.1 \\
\hline DLS $_{05}$ & 0.45 & 2.86 \\
\hline
\end{tabular}

Table 4 presents the results of the effect of mechanically activated zeolite on the vital activity of soil microorganisms. Basal respiration indicates the ability of the microbial community to mineralize organic matter in the soil, and microbial biomass indicates the state of the soil biocenosis. An increase in basal respiration is characterized by the release of $\mathrm{CO}_{2}$ from $100 \mathrm{~cm}^{2}$ of the soil surface, which is apparently associated with a growth of the microbial biomass.

The greatest amount of $\mathrm{CO}_{2}$ emitted from $100 \mathrm{~cm}^{2}$ of the soil surface was noted when using the maximum dose $(15 \mathrm{t} / \mathrm{ha})$ of mechanically activated zeolite - by 3.1 $\mathrm{mg} / 100 \mathrm{~g} * 24$ hours. At the same time, the biomass of microorganisms increased by 4.7 and $15.5 \mathrm{mg} / 100 \mathrm{~g} * \mathrm{~h}$, respectively, the doses of mineral 10 and 15 t/ha to the background.

These factors had a positive impact on the productivity of cultivated crops (Table 5).

Table 5. Effect of mechanically activated zeolite on crop yields, t/ha

\begin{tabular}{|c|c|c|c|c|c|c|c|}
\hline \multirow[t]{2}{*}{ Variant } & \multicolumn{3}{|c|}{ Yield } & \multirow{2}{*}{$\begin{array}{l}\text { Output of grain } \\
\text { for } 3 \text { years, } \\
\text { grain units }\end{array}$} & \multicolumn{2}{|c|}{$\begin{array}{l}\text { Mid-year yield gain, } \\
\text { grain units }\end{array}$} & \multirow{2}{*}{$\begin{array}{c}\text { Rate of return } \\
1 \mathrm{t} \mathrm{MZ,} \\
\text { grain units }\end{array}$} \\
\hline & spring barley & sugarbeet & spring wheat & & to background & to control & \\
\hline Control & 2.2 & 16.8 & 1.6 & 2.7 & - & - & - \\
\hline $\mathrm{N}_{60} \mathrm{P}_{60} \mathrm{~K}_{60}-$ background & 2.7 & 22.3 & 2.1 & 3.5 & - & 0.8 & - \\
\hline background + MZ $10 \mathrm{t} / \mathrm{ha}$ & 2.8 & 24.3 & 2.4 & 3.8 & 0.3 & 1.1 & 0.11 \\
\hline background + MZ $15 \mathrm{t} / \mathrm{ha}$ & 2.9 & 25.5 & 2.6 & 4.0 & 0.5 & 1.3 & 0.09 \\
\hline $\mathrm{DLS}_{0.5}$ & 0.22 & 4.29 & 0.24 & & & & \\
\hline
\end{tabular}

The reliable increase in the yield of spring barley grain under the influence of mechanically activated zeolite was, in comparison with the control -0.6 and 0.7 t/ha, with the background -0.1 and $0.2 \mathrm{t} / \mathrm{ha}$, respectively, the doses of 10 and 15 t/ha. The yield of sugar beet increased in comparison with the control - by 7.5 and 8.7 t/ha, with the background - by 2.0 and 3.2 t/ha, respectively. Compared to the control, additional gains in the yield of spring wheat grain amounted to 0.8 and $1.0 \mathrm{t} / \mathrm{ha}$, with a background of 0.3 and $0.5 \mathrm{t} / \mathrm{ha}$, respectively, of 10 and $15 \mathrm{t} / \mathrm{ha}$ zeolite doses.

Thus, estimating the return on yield of 1 ton of studied doses of zeolite 10 and $15 \mathrm{t} / \mathrm{ha}$, which amounted to 1.1 and 0.9 centners of grain units to increase crop yields, it is more expedient to use a mineral in a lower dose - 10 t/ha.

Vegetation studies on gray forest medium loamy soil using mechanically activated and nanostructured zeolite showed an improvement in the response of the soil environment (Table 6).

The shift of $\mathrm{pH}_{\text {sol }}$ to the neutral side under the influence of mechanically activated zeolite at a dose of $15 \mathrm{t} /$ ha amounted to 0.99 units, nanostructured zeolite at doses of 0.1 and $1.0 \mathrm{t} / \mathrm{ha}-0.97$ and 0.9 units to a background concentration, respectively. Similarly, hydrolytic acidity decreased, when using mechanically activated zeolite - by $0.52 \mathrm{cmol}$ (eq.) $/ \mathrm{kg}$ of soil, nanostructured analog in doses of 0.1 and $1.0 \mathrm{t} / \mathrm{ha}-$ by 0.09 and $0.10 \mathrm{cmol}$ (eq) $/ \mathrm{kg}$, respectively, to the background.
An improvement in the reaction of the soil environment was accompanied by an increase in the amount of absorbed bases, in the variant with mechanically activated zeolite - by $0.8 \mathrm{cmol}$ (eq.) $/ \mathrm{kg}$ of soil, nanostructured - by 1.4 and $10.8 \mathrm{cmol}$ (eq.) $/ \mathrm{kg}$ of soil, respectively, with doses of 0.1 and 1.0 t/ha to the background.

An increase in the content of mineral nitrogen in the soil, especially ammonia, was observed. Its reserves under the influence of mechanically activated zeolite increased by $0.8 \mathrm{mg} / \mathrm{kg}$, nanostructured zeolite in doses of 0.1 and $1.0 \mathrm{t} / \mathrm{ha}$ - by 0.8 and $2.4 \mathrm{mg} / \mathrm{kg}$ to the background, respectively.

When using mechanoactivated zeolite in the soil, the content of mobile phosphorus increased by $20.0 \mathrm{mg} / \mathrm{kg}$ of soil. In the variants where the nanostructured analogue was used in doses of 0.1 and $1.0 \mathrm{t} / \mathrm{ha}$, the availability of the studied element increased by 6.0 and $33.0 \mathrm{mg} / \mathrm{kg}$ of soil to the background, respectively. Similarly, the content of exchangeable potassium increased influenced by mechanically activated zeolite by $2.0 \mathrm{mg} / \mathrm{kg}$, nanostructured zeolite in doses of 0.1 and $1.0 \mathrm{t} / \mathrm{ha}$ - by 3.0 and $5.5 \mathrm{mg} / \mathrm{kg}$ against the background, respectively.

Analysis of the yield data shows that the largest grain weight was obtained in the variant with nanostructured zeolite at a dose of $1.0 \mathrm{t} / \mathrm{ha}-26.9 \mathrm{~g} / \mathrm{vessel}$, the increase was $-10.9 \mathrm{~g} / \mathrm{vessel}$. Grain yield increases in the variants with mechanically activated zeolite at a dose of $15 \mathrm{t} / \mathrm{ha}$ and a nanostructured analog at a dose of $0.1 \mathrm{t} / \mathrm{ha}$ were comparable. 
Table 6. Effect of mechanically activated and nanostructured zeolite on agrochemical properties of gray forest soil and buckwheat yield, g/vessel

\begin{tabular}{|c|c|c|c|c|c|c|c|c|c|}
\hline \multirow[b]{2}{*}{ Variant } & \multirow{2}{*}{$\begin{array}{c}\text { Humus, } \\
\%\end{array}$} & \multirow[b]{2}{*}{$\mathrm{pH}_{\text {sol. }}$} & \multirow{2}{*}{$\begin{array}{c}\mathrm{H}_{\mathrm{g}}, \\
\mathrm{cmol}(\mathrm{eq}) / \mathrm{kg}\end{array}$} & \multirow{2}{*}{$\begin{array}{c}\mathrm{S}, \\
\mathrm{cmol}(\mathrm{eq}) / \mathrm{kg}\end{array}$} & \multirow{2}{*}{$\begin{array}{l}\mathrm{NH}_{4}, \\
\mathrm{Mg} / \mathrm{Kg}\end{array}$} & \multirow{2}{*}{$\begin{array}{l}\mathrm{P}_{2} \mathrm{O}_{5} \\
\mathrm{Mg} / \mathrm{Kg}\end{array}$} & \multirow{2}{*}{$\begin{array}{l}\mathrm{K}_{2} \mathrm{O}, \\
\mathrm{Mg} / \mathrm{Kg}\end{array}$} & \multicolumn{2}{|c|}{ Yield, g/vessel } \\
\hline & & & & & & & & Total & Gain \\
\hline Control & 3.2 & 5.50 & 2.74 & 23.0 & 5.0 & 139.0 & 54.5 & 16.0 & - \\
\hline $\mathrm{N}_{60} \mathrm{P}_{60} \mathrm{~K}$ - background & 3.2 & 5.52 & 2.41 & 23.6 & 5.0 & 150.0 & 59.0 & 19.5 & 3.5 \\
\hline Background + MZ $15.0 \mathrm{t} / \mathrm{ha}$ & 3.2 & 6.51 & 1.89 & 24.4 & 5.8 & 170.0 & 61.0 & 24.6 & 8.6 \\
\hline Background $+\mathrm{NZ} * * 0.1 \mathrm{t} / \mathrm{ha}$ & 3.2 & 6.49 & 2.32 & 25.0 & 5.8 & 156.0 & 62.0 & 23.3 & 7.3 \\
\hline Background + NZ 1.0 t/ha & 3.3 & 6.42 & 2.31 & 34.4 & 7.4 & 183.0 & 64.5 & 26.9 & 10.9 \\
\hline
\end{tabular}

Note: NZ ** - nanostructured zeolite

The use of both mechanically activated and nanostructured zeolite contributed to an increase in the respiratory activity of the soil, which varied according to the variants of experience in the range from 27.3 to 57.9 $\mathrm{mg} \mathrm{CO} / 100 \mathrm{~g} * 24 \mathrm{~h}$ of soil. When using mechanically activated zeolite at a dose of $15.0 \mathrm{t} / \mathrm{ha}$, the microbial soil biomass increased by $3.2 \mathrm{mg} / 100 \mathrm{~g} * \mathrm{~h}$, the nanostructured analog - by 3.0 and $24.0 \mathrm{mg} / 100 \mathrm{~g} * \mathrm{~h}$ to the background, respectively, at 0.1 and $1.0 \mathrm{t} / \mathrm{ha}$ doses (Table 7).

Table 7. Effect of mechanically activated and nanostructured zeolite on basal respiration and microbial soil biomass

\begin{tabular}{|c|c|c|}
\hline Variant & $\begin{array}{c}\text { Amount of } \\
\text { evolved } \mathrm{CO}_{2}, \\
\mathrm{mg} / 100 \mathrm{~g} * 24 \mathrm{~h}\end{array}$ & $\begin{array}{c}\text { Microbial soil } \\
\text { biomass, } \\
\mathrm{Mg} / 100 \mathrm{~g} * \mathrm{~h}\end{array}$ \\
\hline Control & 27.3 & 51.3 \\
\hline NPK - background 60 kg/ha & 34.7 & 54.1 \\
\hline Background + zeolite 15 t/ha & 44.0 & 57.3 \\
\hline Background + NZ 0.1 t/ha & 38.7 & 57.1 \\
\hline Background + NZ 1.0 t/ha & 57.9 & 78.1 \\
\hline
\end{tabular}

\section{Conclusion}

Based on the data obtained, we can draw the following conclusions:

1. Zeolite-containing rocks, improving the agrochemical and agrophysical properties of the soil, increased soil fertility. At the same time, favorable conditions were created for enhancing the growth and development of plants. Grain yield increases amounted to -0.3 and $0.5 \mathrm{t} / \mathrm{ha}$.

2. The efficiency of mechanically activated zeolite at a dose of $15 \mathrm{t} / \mathrm{ha}$ and a nanostructured analog at a dose of $0.1 \mathrm{t} / \mathrm{ha}$ is comparable at a consumption of the latter 150 times less.

\section{References}

1. A.Kh. Yapparov, L.M.-Kh. Bikkinina, I.A. Yapparov et al., Eurasian Soil Sci. 48, 1149-1158 (2015)

2. V.N. Kapranov, Using natural agro-chemical means as sources of minerals for field crops, PhD dissertation (Moscow, 2009)

3. N.V. Zaimenko, N.P. Didyk, N.E. Ellanska et al., Sci. and Innovat. 12, 58-68 (2016)

4. A.M. Ezhkova, A.Kh. Yapparov, V.O. Ezhkov et al., Proc. Biolog. Sci. 467, 65-67 (2016)

5. R. Kulasekaran, R. Damodar, B. Kumar, Advances in Agronomy 113, 215-236 (Academic Press Publ., 2011)

6. A. Bernardi, P. Oliviera, M. Monte, F. SousaBarros, Microporous and Mesoporous Materials 167, 16-21 (2013)

7. A.I. Burov, A.N. Tyurin, A.V. Yakimov, T.Kh. Ishkaeb, Zeolite-containing rocks of Tatarstan and their applications (FEN, Kazan, 2001)

8. B.A. Sushenitsa, Phosphate content of soils and its regulation (Moscow, 2007)

9. J. Bloem, D. Hopkins, A. Benedetti, Microbiological methods for assessing soil quality (CABI Publ., 2006)

10. R. Borges, F. S. Brunatto, A. Leitao, Clay minerals 50, 153-162 (2015)

11. F. Pereira, E. Paris, J. Bresolin, Ecotoxicology and environmental safety 144, 138-147 (2017)

12. M.R. Khan, T.F. Rizvil, Nanoscience and plant-soil systems 48, 405-427 (2017) 